\title{
The Effect of Water Quality on Dewatering Properties of Debswana Kimberlitic Ores
}

\author{
K. Ntshabele Debswana Diamond Mining Company, Botswana \\ M. Cooks Debswana Diamond Mining Company, Botswana \\ B. Busani Debswana Diamond Mining Company, Botswana
}

J. Dodo Debswana Diamond Mining Company, Botswana

\begin{abstract}
Different water qualities are found at each of the Debswana operations. Tests with water from three different operations were done, on the same ore samples, to study the influence of water quality on the dewatering characteristics of the resultant slurries. Using the same methodology and water, the different ore types produced slurries with different percentage solids and particle size distributions. For the same ore type, a change in water quality resulted in a change in slurry characteristics.

The dewatering behaviour of the slurries, as expressed in terms of thickener underflow density, was related to ore type and water quality. Some ores from the different operations had similar dewatering characteristics. The ore type as well as water quality influenced the water demand of the process. It was concluded that the water quality plays an important role in the water recovery at the Debswana operations. This work showed that the water recovery can be improved if the water quality is controlled.
\end{abstract}

\section{Introduction}

Debswana has embarked on measures to reduce water consumption at its process plants by $50 \%$ by 2008 . Efficient dewatering of the fines residue from the plant to recover more process water was identified as a major contributor towards this objective. A fundamental understanding of the drivers in process water recovery from the fine residue was needed.

Thirteen different ore types from four operations in combination with three different water qualities from the three operations were investigated. In this paper, the effects of water quality on the ability of Debswana ores to release water is discussed.

\section{Materials}

Thirteen different ore types were taken from four different kimberlite pits operated by Debswana mines. The samples were taken after consultation with the mine geologists as to the location of specific ore types in the pit.

Bulk samples of $10 \mathrm{t}$ were crushed to smaller than $35 \mathrm{~mm}$ and reduced to $5 \mathrm{t}$ samples. The five $\mathrm{t}$ samples were stored, on pallets, in one t bulk bags under tarpaulin covers.

The samples were coded according to the mine and the ore type. Orapa mine was coded as OM; Letlhakane mine as LM; Damtshaa mine as DM and Jwaneng mine as JM. The ore type code forms the last part of the sample name. The samples were: OM SVK; OM NPK; OM Basalt; OM A3T; LM 2E; LM 2W; LM1; DM321; DMBK12; DM311; JM VK South lobe; JM Centre lobe and JM Pyroclastic.

Water samples were collected at three of the operations: Jwaneng mine; Orapa mine and Letlhakane mine. The Jwaneng water is potable water with low conductivity and salinity levels; Orapa water has higher conductivity and salinity levels, while Letlhakane water has the highest conductivity and salinity levels. 
Adding the correct amount and type of flocculant will ensure optimal thickener performance.

High saline and hard water will induce coagulation in the slurry before flocculation occurs. This leads to consolidation of the bed while it is still at a low level. The results are graphically presented in Figure 8. The difference in the shape of the curves indicates a difference in the bed characteristics. The Letlhakane water produced a more linear curve, while the Orapa and Jwaneng waters produced S-shaped curves. The compressive forces exerted by the bed are required to expel water from the bed.

Most of the ores have the same optimum bed height for all three water qualities. Table 3 shows that the change in water quality does not affect the optimum thickener mud bed depth in general.

Ores will change the process water quality as water is recovered and recycled through the plant several times. An increase in slurry zeta potential was observed. Due to repulsive forces between clay particles, the void ratio will be increased. As a result the bed formed will contain interstitial water leading to a drop in underflow density.

\section{Conclusions}

The ore PSD and clay dispersion behaviour will be influenced up-front by the water quality.

From Figures 8 and Table 3 it was found that the optimum bed height is not influenced by the water quality, but rather by the ore type.

The high salt content, as indicated by the conductivity of the process water together with low clay contents of the ore, explains why Damtshaa and Letlhakane mines require less water than the other two operations.

It can further be concluded that:

- Water recovery in the thickener and water consumption per $t$ of ore are dependant on the water quality.

- For better thickener performance saline and high calcium concentration (high hardness) water like the Letlhakane water is required.

- Orapa water is not far off from the quality needed.

- An improvement in water recovery would increase the water recirculation in the plant. The thickener operation will be adversely influenced as the water recirculation is increased. The new equilibrium would be at reduced water consumption levels. The decrease in water consumption after the introduction of more saline water will therefore be gradual.

\section{Acknowledgements}

The authors would like to acknowledge Debswana and Orapa mine management for all the support during the project and approval to publish this paper. 